\title{
e-Government for Public Values creation: a systematic literature review
}

\author{
Giulia Maragno \\ Department of Management, \\ Economics, and Industrial \\ Engineering, Politecnico di Milano, \\ Via Raffaele Lambruschini 4/b, 20156 \\ Milan, Italy \\ giulia.maragno@polimi.it
}

\author{
Luca Gastaldi \\ Department of Management, \\ Economics, and Industrial \\ Engineering, Politecnico di Milano, \\ Via Raffaele Lambruschini 4/b, 20156 \\ Milan, Italy \\ luca.gastaldi@polimi.it
}

\author{
Mariano Corso \\ Department of Management, \\ Economics, and Industrial \\ Engineering, Politecnico di Milano, \\ Via Raffaele Lambruschini 4/b, 20156 \\ Milan, Italy \\ mariano.corso@polimi.it
}

\begin{abstract}
Scholars and practitioners attention to the benefits enhanced by e-Government projects is progressively increasing. These transformations generated and are continuously generating new challenges for managing public organizations which cannot focus only on administrative efficiency but have to embrace a broader set of values. In this scenario, the adoption of digital technologies within governments could potentially have disrupting effects, both positive and negative. However, despite the general hype, few public organizations have actually realised all the potential associated with the adoption of digital technologies as values enablers: this study aims to investigate the topic by examining how it has evolved throughout the years and organizing the state-of-the-art of the scientific literature on public values creation through e-Government projects. Based on the literature review, we provide a conceptual framework for understanding the factors that are related and influence e-Government implementation and its benefits. Findings suggest that before considering the implementation of an e-Government project, and thus the achievement of specific benefits, a set of different variables should be addressed.
\end{abstract}

\section{CCS CONCEPTS}

-Applied computing $\rightarrow$ Computers in other domains; Computing in government; E-government.

\section{KEYWORDS}

e-Government, literature review, public values

\section{ACM Reference Format:}

Giulia Maragno, Luca Gastaldi, and Mariano Corso. 2021. e-Government for Public Values creation: a systematic literature review. In DG.O2021: The 22nd Annual International Conference on Digital Government Research (DG.O'21), fune 09-11, 2021, Omaha, NE, USA. ACM, New York, NY, USA, 12 pages. https://doi.org/10.1145/3463677.3463692

Permission to make digital or hard copies of all or part of this work for personal or classroom use is granted without fee provided that copies are not made or distributed for profit or commercial advantage and that copies bear this notice and the full citation on the first page. Copyrights for components of this work owned by others than ACM must be honored. Abstracting with credit is permitted. To copy otherwise, or republish, to post on servers or to redistribute to lists, requires prior specific permission and/or a fee. Request permissions from permissions@acm.org.

DG.O'21, June 09-11, 2021, Omaha, NE, USA

(C) 2021 Association for Computing Machinery.

ACM ISBN 978-1-4503-8492-6/21/06 . \$ \$15.00

https://doi.org/10.1145/3463677.3463692

\section{INTRODUCTION}

During the last decades, private and public organizations are facing numerous challenges due to the rapid changes in cultural, socioeconomic and technological fields. Among others, digital innovation has increasingly become a crucial piece in the development of companies [1] and public organizations [2] and has evolved in both sectors according to the respective features [3].

Considering the latter, it is broadly accepted that the adoption of digital technologies within the public domain, defined as "digital government" $[4,5]$, has become a key goal in political agenda and governmental strategic programs [6] and it is essential for building effective, accountable, inclusive institutions and for engaging citizens [7].

Nevertheless, despite the growing attention, public organizations are often seen as "the dinosaurs of the digital era" [8], lagging behind in their digital transformation for several reasons: regulatory aspects, which reduce the alternatives of digital innovation that can be pursued [9]; the need of coping with a vast array of highly different requirements, expressed by citizens [10], while rethinking their role and redesigning internal procedures and services [11, 12]; the struggles in the identification of the most suitable technologies to adopt, also in relation to a lack of resources [13] and general political myopia [14].

Moreover, the development of e-Government projects need to be contextualized into the scope of public organizations: if the extent of the private sector is to create private value, the public sector must not serve special interests, but the society as a whole [15, 17]. In the last century, public organizations have pursued this aim according to the features of the sector's reforms: Traditional Public Administration, New Public Management (NPM) and, recently, the approaches of Public Value and New Public Service. Each of them arises as a response to societal conditions and challenges, impacting also on the role of digital technologies.

Despite the general hype and years of research on the topic, few public organizations have actually realised all the potential associated with the adoption of digital technologies as value enablers $[18,19]$ and different researchers $[5,17,21]$ pointed out the need of investigating how these technologies could support public values creation. Thus, the aim of this study is to map and to organize the current state-of-the-art of public value creation through e-Government projects, deepening how the topic evolved throughout the years and how the scientific community is debating the 
theme. Moreover, we provide an overview of the variables that, according to the extant academic knowledge, are related and influence e-Government implementation and its benefits.

The subsequent research questions will be addressed: which is the state-of-the-art of public value in e-Government projects and which are the variables related to the delivery of public values through e-Government? We aim at answering these questions through a review of the existing academic knowledge and the development of a conceptual framework that can support researchers and public organizations in the identification of the key factors that should be considered when implementing an e-Government project.

The paper is structured as follows: in the next section we start with a brief theoretical background of the studies related to the adoption of digital technologies and their potential values. In Section 3 we present the methodology adopted for the literature review and then (Section 4) the findings. Next, the conceptual framework for analysing the factors related to the development of e-Government projects and their benefits is discussed, followed by the conclusions and the limitations of the study.

\section{THEORETICAL BACKGROUND}

The literature on digital technologies adoption within the public sector and the potential benefits that they deliver is growing. According to Moore (1995), public value is an abstract concept, because it depends on public needs, that are changing.

As Panagiotopoulos et al. [18] point out, Moore's theory does not specifically address the issue of public organizations' digitalization, but it gives elements to study the digital transformation of the public sector. Bannister and Connolly [20] affirm that public sector values are different and that there is not a unique classification. Moreover, the authors state that any implementation of digital technologies will affect public values, with positive or negative impacts. Thus, to analyse the effects of digital technologies, they propose a taxonomy identifying three broad groups of values, i.e. duty oriented, service oriented and socially oriented. According to Cordella and Paletti [22], public value creation regards both production processes and managerial actions and it is thus necessary to balance different outcomes.

The concept of balance is presented also by Bonina and Cordella [23], even if with a focus on values, not on organizational capability. Considering only the specific set of values related to "good administration" [24], the authors propose a framework that distinguishes between managerial values - like efficiency and effectiveness - and democratic values - such as equity and fairness - which could be also overlapping. In this scenario, they state that the adoption of digital technologies is a matter of harmonizing competing public values, in their managerial and democratic nature. Similarly, Twizeyimana and Andersson [21] identify six overlapping dimensions of values, that they group into three overarching areas: Improved Administration, Improved Social Value and Improved Public Services.

The idea of different value positions, convergent and divergent, is proposed by Rose et al. [17]. The authors present a framework that allows the identification of four value propositions: professionalism, efficiency, service and engagement. All these ideals are linked to a specific public management theoretical approach and authors relate each of these propositions to e-Government. Considering the Public Value narrative, Rose et al. [17] state that digital technologies are seen as tools to increase services' availability and quality, thus as service enablers. Always considering the role of services, in their research Golubeva and Gilenko [25] examine the possible advantages of e-services on public value. The authors consider the local level, stating that public value and citizens' needs can be assessed most accurately. Besides, the interaction between citizens and public administrators is more direct.

Cordella and Dodd [26] assert that value is not simply produced by organizations, but it originates from service delivery and the usage of a specific service. This view implies a strong connection between users, their needs and service providers: digital technologies, according to the authors, can facilitate these connections. The need to understand stakeholders' interests and their value positions in e-Government projects is highlighted also by Rose et al. [27]. In line with them, Luna-Reyes et al. [28] affirm that the adoption of digital technologies to support government tasks and public service delivery creates value.

Lessa and Tsegaye [29], adopting a broader perspective, state that public value can be seen as the importance that citizens give both to government actions and to the experience they have of public services. Lindgren and van Veenstra [30] assert that to enhance public sector transformation using the value creation lens, the digitalization of public services is the key. Hence, they propose a conceptual framework, based on two concepts (transformational objectives; enabling mechanism), to explain the transformation enabled by e-Government. Valle-Cruz [31] rests also on an overarching level, stating that public value is generated by services, laws and actions and it concerns public policies objectives and performance. In this view, emerging technologies support public organizations in service delivery.

According to Cordella and Bonina [19], public sector ICT reforms have broadly omitted public value creation and the authors state that considering this new paradigm will allow a better assessment of digital technologies in the public sphere.

In addition, different authors point out the importance of interorganizational collaboration on public value creation. In their research, Luna-Reyes et al. [32] identify different elements that influence public value creation: organizational factors and technologies directly affect public value creation, while institutional arrangements impact on technologies. Picazo-Vela et al. [33] address the same theme from another perspective, i.e. the impact of publicprivate and public-public collaborations on public value creation in the e-Government context.

This brief analysis confirms Bannister and Connolly [20] statement that technologies are not value free and, as Rose et al. [17] claim, that examining the benefits inherent in e-Government projects is a way to comprehend their superior objectives. However, the potential values reached by the adoption of digital technologies are the tip of the iceberg and, in line with the aim of this study, it is necessary to deepen the underlying factors. 


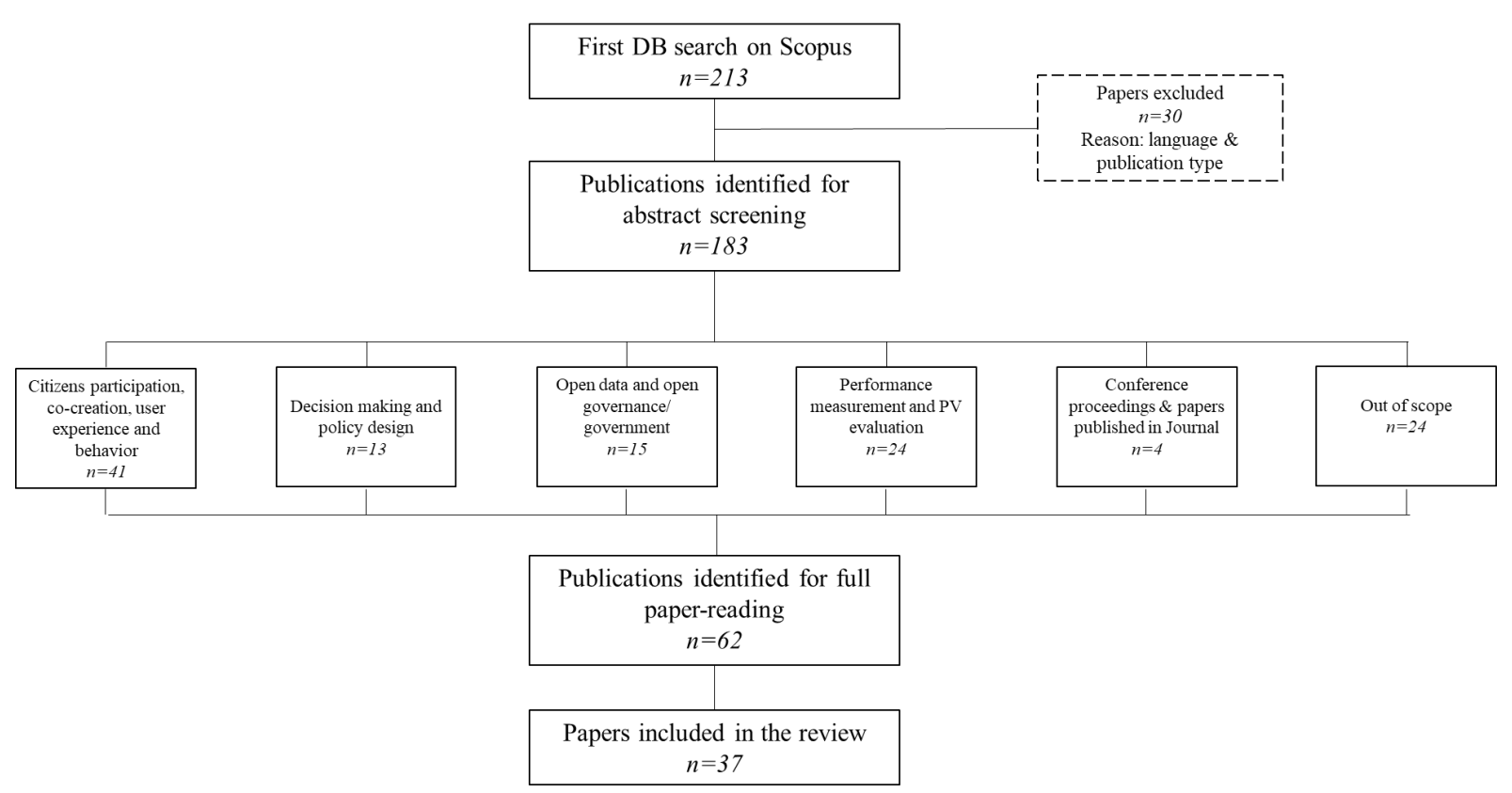

Figure 1: PRISMA Flow chart

\section{RESEARCH METHOD}

To map the extant literature on public value and the pivotal role of digital technologies in creating it, a systematic search was conducted. This section describes the methodology adopted: the guidelines proposed by [34] were followed for the systematic search process to reduce bias, allow falsification and reproduction of the results.

First, after the reading of some relevant papers and practitioner reports, we defined a set of specific keywords: e-government, public administration, public value and digital technologies. The keywords were then combined using AND/OR operators to produce the research query: "public value " AND ("e-gov*” OR "egov" OR "digital government"). Asterisks were set to include suffixes.

The choice to include "egovernment" and "e-government" is due to the presence of both in academic and practitioner documents. Analogously, academics and practitioners use also "digital government" regarding the application of digital technologies in the public sphere. The research string was run on Scopus database and title, abstract and keywords were used to identify the publications: the search isolated 213 contributions (up to January 11th, 2021). Additional inclusion and exclusion criteria were then applied to refine the results. To be included in the review, documents should i) be written in English and be publicly available; ii) be published in article, conference paper, review and editorial; iii) be focused on the adoption of digital technologies as tools to enhance public values creation; iv) be focused on public organisations in relation to public values. Publications presenting the following criteria were instead excluded:

- conference papers, if the same contribution was then published in journal;
- contributions related to citizens' involvement in public values' co-creation, as they focus more on the participatory and democratic side of public management (i.e. New Public Service approach); with this aim in mind, social media application were also excluded;

- essays related to performance measurement, as the study starts from the previous step, i.e. whether the application of digital technologies could enhance public values and which are the factors that enhance, or obstruct, it;

- contributions related to open government data, as it is rather a broad topic, addressing both open innovation and the management of the remarkable quantity of public data.

We applied the inclusion criteria i) and ii) to the papers selected, reaching 183 documents. The exclusion criteria were not applied a priori: to be sure to not miss any relevant document, the abstract screening comprehends all the selected contributions. Furthermore, no filter was applied a priori on the year.

The abstracts were thus read and we applied the exclusion criteria: if the content was not fully clear, the paper was included for full reading. At the end, 37 publications were selected as the final source of the research: the PRISMA flow chart [35] (Figure 1) shows the screening process described above.

\section{FINDINGS}

The review aimed to map and organize the existent literature on public values delivered through e-Government projects. We firstly performed a quantitative review to point out the main features of the dataset. Then, through a content analysis, we identify the variables that affect e-Government projects development. 


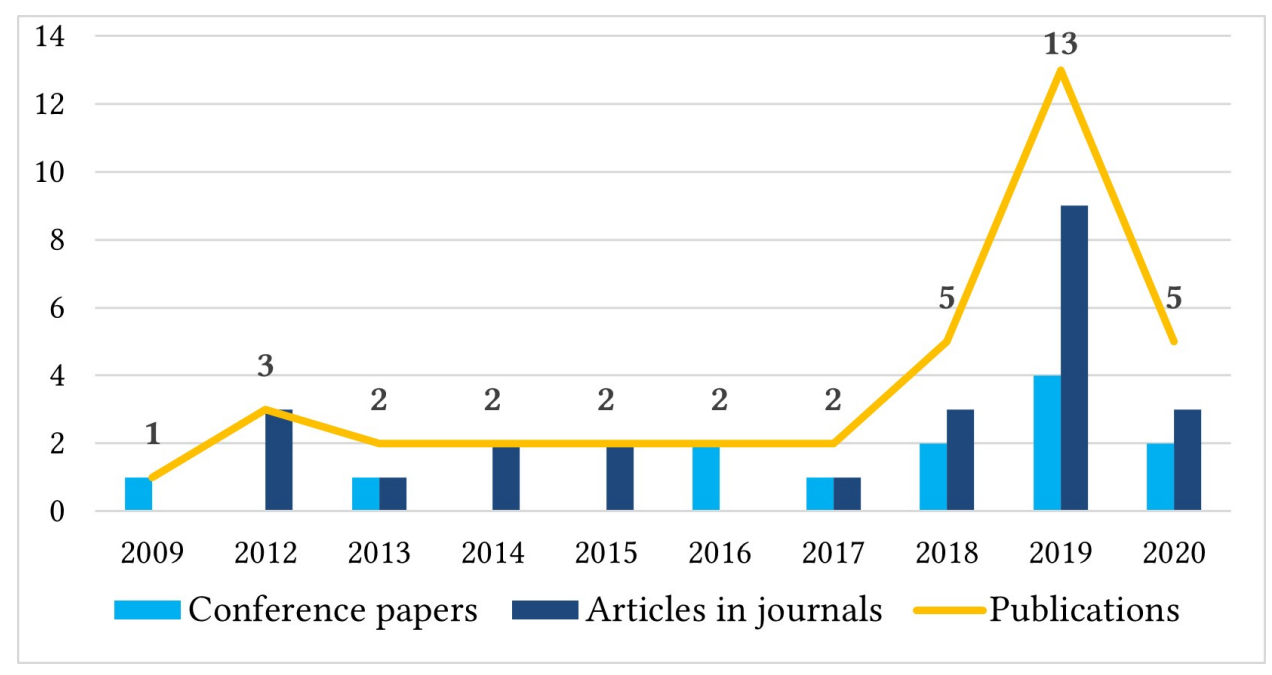

Figure 2: Publications trend over the last ten years

\subsection{Papers main features}

In recent years, the interest of practitioners at the interplay between public value and digital technologies is increased [4, 7]. The topic is gaining momentum also in the scientific community: if between 2009 and 2017 the trend of publications was quite stable, a continuous increase can be noticed since 2018 .

From 2017 and 2019 the number of publications has grown constantly, showing a peak in 2019 (Figure 2) and indicating that the attention on public values in e-Government has acquired relevance.

Regarding the source of contributions, most of them are published in journals $(65 \%)$ and 13 were published in conference proceedings (35\%). Considering the theoretical field, the contributions under review come both from social science and computer science communities, showing the interdisciplinarity of the topic. However, as depicted in Table 1, most contributions are in the computer science area (49\%), even if the majority of the articles (12) are published in Government Information Quarterly, showing the growing need to deepen the topic not just considering the technological lens, but also addressing the relationship between policy, the public sector and the use of technologies to support services' development and provision.

When considering the e-Government level of domain, the publications discuss mostly (16) the scenario of central public organizations $[22,26,27,29,30,32,33,36,44]$ and just six articles present the local level [25, 31, 45, 48], plus one that generally addresses the topic of smart cities [49].

Two studies investigate cross-country issue $[50,51]$ while the remaining contributions do not have any specific focus. Considering the level of government, it is interesting to note that there is an equal distribution between studies addressing e-Government advancement in developing countries while local studies are conducted mainly in developed countries. This might suggest that the digital transformation of public organizations starts from the central level, which generally has enough resources and competences to develop and complete such processes, to then unfold at the local level.

\subsection{Content analysis}

The content analysis allows us to highlight the main elements that, according to the existing academic literature, should be considered when developing an e-Government project: potential benefits, areas of impact and conditions enabling, or obstructing, the project implementation. Thus, the evidence emerged are presented following these three dimensions.

4.2.1 Benefits of e-Government projects. The review points out a number of positive values that we categorized according to the dimensions proposed by [21]. This framework identifies six overlapping dimensions of public values of e-Government: Improved public services; Improved administrative efficiency; Open Government capabilities; Improved ethical behaviour and professionalism; Improved trust and confidence in government; Improved social value and well-being.

The authors then identify three main areas, grouping together the dimensions that seem related: Improved administrative efficiency; Open Government capabilities and Improved ethical behaviour and professionalism are linked with government administration, thus they belong to the Improved Administration dimension. Improved trust and confidence in government and Improved social value and well-being are instead related to the social benefits that government is supposed to yield and thus labelled as Improved Social Value. Finally, Improved Public Services refers to the implementation of services that e-Government solutions could enhance.

The framework developed by [21] has been chosen because it proposes a high level of granularity, it is clear the difference between values and it is an updated model compared to others [20, 24]. Appendix A presents the papers that address each dimension.

Improved Administration. Improved administrative efficiency 
Table 1: Source titles and subject area of the dataset

\begin{tabular}{|c|c|c|}
\hline Source & Scimago Subject Area & Publication \\
\hline Government Information Quarterly & Social Science & 12 \\
\hline ACM International Conference Proceeding Series & Computer Science & 7 \\
\hline Information Polity & Computer Science & 3 \\
\hline Communications in Computer and Information & Computer Science & 2 \\
\hline \multicolumn{3}{|l|}{ Science } \\
\hline Lecture Notes in Computer Science & Computer Science & 2 \\
\hline Public Management Review & $\begin{array}{l}\text { Business, Management, Accounting/ } \\
\text { Social Science }\end{array}$ & 2 \\
\hline Americas Conference on Information Systems & Computer Science & 1 \\
\hline eJournal of eDemocracy and Open Government & Computer Science & 1 \\
\hline International Journal of Public Administration in the & Computer Science & 1 \\
\hline \multicolumn{3}{|l|}{ Digital Age } \\
\hline International Journal of Public Sector Management & Environmental Science/Social Science & 1 \\
\hline Journal of Strategic Information Systems & $\begin{array}{l}\text { Business, Management, } \\
\text { Accounting/Computer Science/Decision } \\
\text { Science }\end{array}$ & 1 \\
\hline $\begin{array}{l}\text { Lecture Notes of the Institute for Computer Sciences, } \\
\text { Social-Informatics and Telecommunications Engineering }\end{array}$ & Computer Science & 1 \\
\hline $\begin{array}{l}\text { Proceedings of the Annual Hawaii International } \\
\text { Conference on System Sciences }\end{array}$ & Engineering & 1 \\
\hline $\begin{array}{l}\text { Proceedings of the European Conference on e- } \\
\text { Government }\end{array}$ & $\begin{array}{l}\text { Business, Management, } \\
\text { Accounting/Computer Science/Social } \\
\text { Science }\end{array}$ & 1 \\
\hline Transforming Government: People, Process and Policy & $\begin{array}{l}\text { Computer science/Decision Science/ } \\
\text { Social Science }\end{array}$ & 1 \\
\hline Total & & 37 \\
\hline
\end{tabular}

This layer refers to the effects that the development of eGovernment projects could have on public organizations activities and processes. For instance, e-Government could enhance the accountability within the organization $[20,45,51]$ or could impact on cost reduction, both considering saving time for personnel [36] or processes management [36, 45, 52, 53].

This dimension regards also benefits such as efficiency $[18,23$, $40,42,50,53]$ and effectiveness [23, 50]. Improved administrative efficiency also refers to increasing the competitiveness [36] of public organizations and, thanks to Artificial Intelligence (AI) adoption, process automation [26, 42, 45]. The development of e-Government projects could also reduce human errors $[42,52]$ while enhancing the management of public resources $[20,21]$ and making processes more systematic and sustainable [21, 42]. The adoption of digital technologies could also positively impact on governance $[26,52]$ and it is expected that e-Government projects support public organization to act with parsimony [20,23]. According to the literature review made by [52], e-Government projects that employ blockchain solutions are expected to increase organizational resilience, predictive capabilities and reduce energy usage. Moreover, according to their review, blockchain projects could enable data integrity and preservation.

Open Government capabilities
e-Government projects can increase the access to public data assets and public organization's activities, thus enhancing transparency and openness [18, 20, 21, 36, 48, 52]. This dimension refers also to the interaction among public organizations and stakeholder: open government could facilitate consultation with citizens, enterprises and other public bodies [18, 21, 42, 51]. e-Government is expected to enhance the quality of information, in terms of sharing, relevance, accuracy, update, access [21, 36, 40, 52, 53] and data management [36, 52].

Improved ethical behaviour and professionalism

This dimension broadly refers to the "Sigma" [24] and the "Duty orientated" [20] values discussed in the literature. These values are more related to the ethical and individual sphere of public employees: e-Government projects are expected to positively impact on political loyalty [51], judicial values, rectitude and impartiality $[20,51]$, honesty and fairness $[18,20,23]$ and to support civil servants to act in compliance with the law $[20,51]$.

The adoption of digital technologies in public setting could also benefit the control of corruption [50,52], the accountability of public organization's actions towards society [18, 20,45, 50,51] and their responsibility to citizens, enterprises and other public organizations $[20,51]$. The implementation of e-Government projects is 
expected to enhance governments capabilities to protect different stakeholder [20,51].

Improved Public Services. This dimension addresses the different benefits that e-Government projects could have on service improvement. The adoption of digital technologies boosts user interaction [26] and the capability to satisfy their needs [51]. e-Government projects are expected to enhance services in terms of accessibility $[18,42]$, personalization and quality [21, 26, 42, 48, 51, 53], ease of usage [18] and delivery [29, 40]. The improvements concern also public organizations responsiveness to answer citizens' questions and needs [20, 40, 51], efficiency [18, 20, 48, 51] and effectiveness $[20,51]$. Public service enrichment through digital technology could also potentially affect public organizations productivity, their innovation orientation, the respect for individual and the management of public resources [51].

Improved Social Values. Improved trust and confidence in government

This dimension concerns the benefits generated by eGovernment projects that enhance stakeholder confidence in public organizations. For instance, the adoption of digital technologies is expected to increase public trust by guaranteeing equality and equity in service access $[18,20,23,51]$, user privacy $[18,20,52]$, transparency and openness [18, 20, 21, 48, 52].

Leveraging on e-Government projects, public organizations could augment communications to external stakeholder, regarding resources usage and their activities [18, 20, 50, 51], the dialogue within other governments and support networks development [51] The protection of user security could be improved by the adoption of specific technologies [20,52], just as trust [36, 52]. e-Government projects could impact also on public organization ability to balance the competing interests of individuals [51] and confidence could be reached enhancing interaction $[18,20,21,26,42,51]$ and user orientation [23].

Improved social value and well-being

e-Government projects are also seen as a lever for the increase of the social well-being. Thus, their adoption is supposed to facilitate the democratic will $[20,51]$, the inclusiveness and the respect for individuals [20]. e-Government solutions could impact on societal challenges, such as environmental sustainability [43] or the control of corruption [36, 50,52].

4.2.2 Conditions. The literature review points out that most papers addressing public values of e-Government actually present conditions that affect the implementation of e-Government projects. These could be divided in: Internal conditions, External conditions and Technological conditions. Appendix B presents the papers that address each dimension.

Internal conditions. Internal conditions refer to the variables peculiar of a single public organization. Internal conditions relate, for example, to strategic decisions, such as the definition of a clear decision making process [30,41,54], project's goal [32] or digital business strategies [44]. Moreover the integration and the dialogue between departments within the public organization could improve e-Government projects [55], just as the collaborative behaviours of employees [44] and the enhancement of collaboration with other organizations, whether they are public, private or community based [30, 32, 33, 44].

According to Savoldelli et al. [56], a public organisation able to overcome the internal resistance to change is facilitate in the development of e-Government solutions; furthermore, organisational capabilities $[18,41,43,56]$ and the improvement of internal processes $[32,33]$ impact the adoption of technological solutions in public sector.

Additionally, Pereira et al. [49] state that, in a smart city context, adequate human resources, as a component of government capabilities, could enable digital transformation and public values. Also, the relation with different stakeholder is crucial: their involvement $[43,47,55,56]$ influence innovation and public organisations should understand their competing expectations $[18,27,44,47,57,58]$ to deliver e-Government projects that satisfy their needs. Still, it is important to discipline the use of outsourcing [42].

External conditions. This set of variables is independent of the internal sphere of the organizations and it is more related to the environmental context in which the public organization works. This group gathers together two sub-factors: Institutional and Citizens' dimensions.

Institutional dimension

According to Savoldelli et al. [56], only recently institutional and political issues draw the attention as crucial factors in the eGovernment context. These arrangements could differ over time, also according to different cultures and countries and, as authors state [56], they become one of the main barriers in the adoption of e-Government. Thus, the implementation of strategies [31, 43] and a clear definition of legal frameworks [30,32] could shape e-Government projects.

Citizens' dimension

This dimension refers to all the factors concerning the users' sphere and their responses in regards to e-Government solutions. Public organizations, when developing an e-Government project, should carefully consider these variables: citizens' access to digital technologies, just as their skills $[25,44,55]$, are crucial for the project success. Moreover, public organisation have to consider, and enhance, citizens awareness of the presence of specific digital projects $[25,44,46]$.

Additionally, citizens could approach and trust technologies in different ways [25]; the availability of projects' information [46], the impact of mass media [41] and the benefits perceived by each citizen $[25,46]$ are other key variables in this dimension.

Technological conditions

Considering technological features, the adoption of technologies is seen as a lever for transformation [49]. However, on one side, the lack of interoperability and the high costs of maintenance of e-Government projects [56] are perceived as conditions that hinder e-Government solutions, just as the lack of an ICT infrastructure $[44,56]$. Their fulfilment depends on public organizations while, on the other side, the development of technology standards, useful to increase the implementation of a specific technology [32], is related to external conditions.

4.2.3 Impacts of e-Government projects. e-Government projects are thus expected to deliver a number of benefits, but it is necessary to deepen the impact they have within public organizations. 


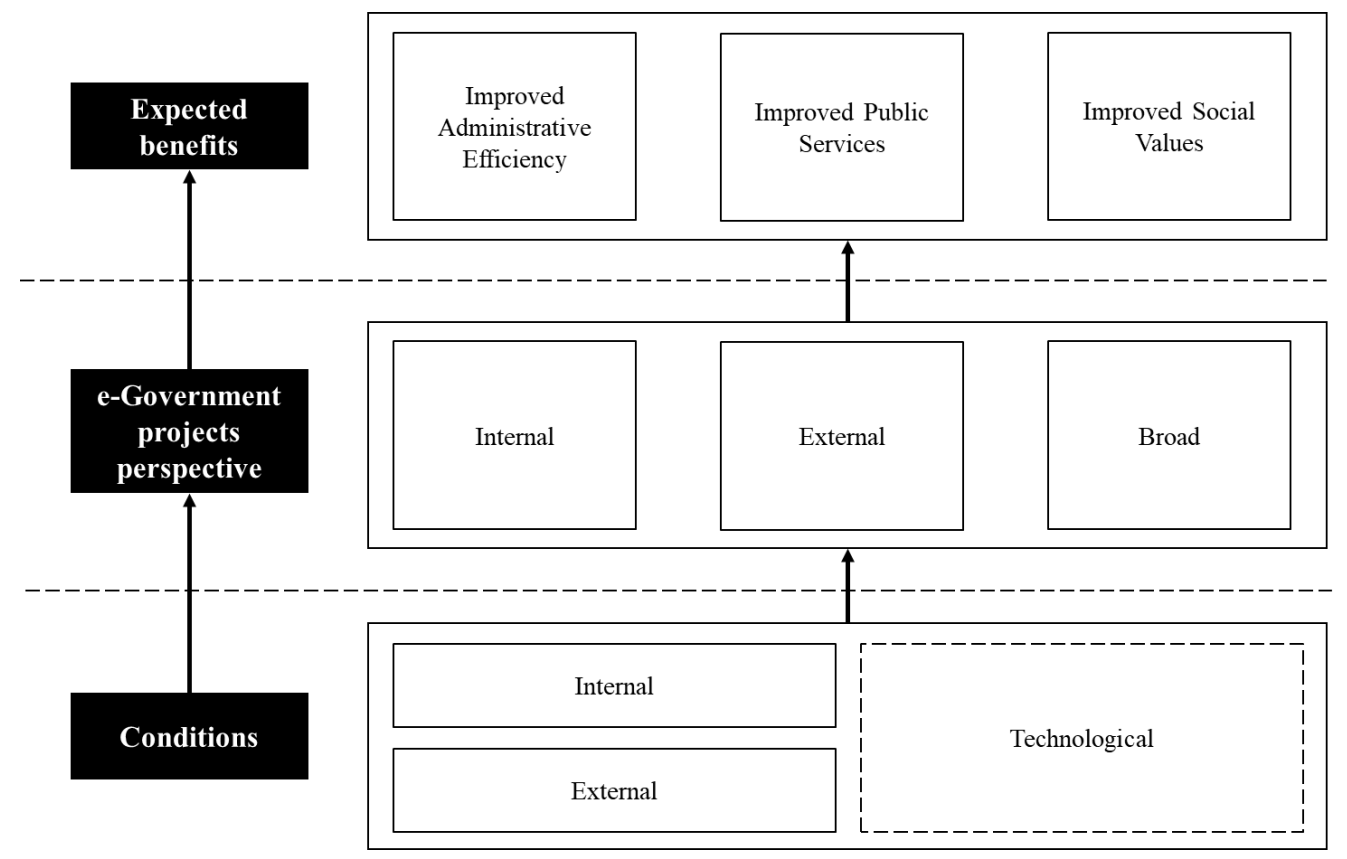

Figure 3: Conceptual framework for public values enhancement through e-Government projects

Thus, as we did for conditions, we classified the articles considering three perspectives: (1) Internal, if the project impacts on public organisation internal processes and management; (2) External, if instead the adoption of digital technologies enhance service delivery and the relation between public organisation and users; (3) Broad, since for some articles it was not possible to clearly identify the application area, so we classified them as having broad impacts.

The review shows that internal and external impacts are frequently overlapping: this is not surprising because also benefits frequently cross each other. Most papers (12) point out that eGovernment projects are implemented to enhance service delivery and user relation, while ten articles focus instead on the internal perspective. Few studies (3) were classified as having broad effects, thus supporting a large set of activities. Appendix $C$ presents the papers that address each dimension.

\section{DISCUSSION}

The study organizes the existing academic knowledge by identifying the main features of the papers reviewed (i.e. data and source of publications, theoretical field, e-Government level of domain) and the content analysis we performed allows us to develop a conceptual framework (Figure 3 ) to provide an inclusive overview of the different factors related the development of e-Government projects and their benefits. There is a need to go beyond the potential benefits that e-Government solutions could produce to understand which factors impact on such projects. Based on this, we proposed a model that starts considering the three main dimensions of public values of e-Government proposed by [21] and then we identify other components that should be considered when addressing the topic of
e-Government projects and their expected benefits. The main components of the framework illustrated in Figure 3 are presented as follows, from below upwards.

The first dimension that emerged regards the conditions that public organisations should consider and, as far as in their sphere of activities, address. Hence, when implementing an e-Government project, three main conditions should be evaluated: internal, external and technological.

Internal conditions refer to the factors strictly related to the organizational structure of the specific public organization. This means that the replication of the same e-Government project in diverse public organizations generates different results according to these conditions. Looking instead at the external conditions, similar organizations - considering for instance their dimension, level of government, public domain - could develop analogous projects, but they may reach different results according to political, institutional and legal frameworks and also considering the citizens' awareness to e-Gvernment solutions. Thus, projects that in a specific context produced certain results may not reach the same outputs in different scenarios.

The last dimension of this layer concerns the technological conditions: they should be examined adopting a double lens, as on one hand they are the responsibility of public organization (i.e. maintenance of the technology) and on the other they fall within the competence of external requirements (i.e. implementation of technology standard). This layer is the first one that should be considered when deciding to implement an e-Government project: overlooking these three features could potentially lead to the failure of an e-Government solution.

The next level addresses the e-Government perspective and it points out the need to identify which application area is involved. 
e-Government projects can impact on public organisation internal processes and management, but they can also enhance service delivery - both as a consequence of the improved internal area or as a separate area of application - affecting the relation between public organisation and users. Moreover, e-Government projects can support a large set of activities.

This dimension is crucial because the application area impacts on the expected benefits that an e-Government project could deliver, presented in the last level of the model.

Thus, referring to the "Expected benefits" layer, we adopt the dimensions of the public value of e-Government proposed by [21]: this level contains the potential benefits that an e-Government solution could bring, once the previous two layers have been carefully evaluated and addressed.

The three levels of the framework are linked together and in particular the second and the third layer influence each other: as a matter of fact, the decision to implement an e-Government project that impacts on the internal application area rather than on the external one leads to the fulfilment of diverse benefits.

\section{CONCLUSION AND LIMITATION}

To conclude, the study contributes to the discussion of public values of e-Government projects both considering theoretical and managerial perspectives. The research has various implications for academia: first, the findings highlight the increasing interest of the scientific community on the topic and they point out how academic knowledge is evolving in the last years. Second, the review provides a critical assessment of the current state-of-the-art: most authors tend, on the one hand, to analyse the conditions enabling e-Government projects and, on the other, to examine the benefits that might be accomplished by adopting digital technologies, but without providing empirical evidence. This demonstrates that there is the need to gather empirical data on the level of development of e-Government project for understanding the reasons behind the trade-off among the benefits described in the scientific knowledge and the real progress of e-Government projects. Third, it organizes the papers in a conceptual framework that highlights which are the factors related to the adoption of e-Government projects and to the fulfilment of the related benefits. The model presented could be adopted to map and perform other literature reviews. The study has implications also for practitioners, providing public managers with an actionable model through which understanding the path for e-Government projects applications and boosting their implementation.

Finally, the research has limitation. The first concerns the database we chose as source for papers selection: we considered just Scopus database and some papers may be omitted; future research may perform the analysis surveying also other datasets. The second limitation regards the model presented: we provide a theoretical framework that should be tested to verify how the layers are connected and if other factors affect the implementation of e-Government projects.

\section{REFERENCES}

[1] N. Bloom, L. Garicano, R. Sadun, and J. Van Reenen, "The distinct effects of information technology and communication technology on firm Organization," Manage. Sci., vol. 60, no. 12, pp. 2859-2885, 2014.
[2] W. L. Currie and J. J. M. Seddon, "A cross-national analysis of eHealth in the European Union: Some policy and research directions," Inf. Manag., vol. 51, no. 6, pp. 783-797, 2014.

[3] K. K. Ganju, P. A. Pavlou, and R. D. Banker, "DOES INFORMATION AND COMMUNICATION TECHNOLOGY LEAD TO THE WELL-BEING OF NATIONS? A COUNTRY -," vol. 40, no. 2, pp. 417-430, 2016.

[4] OECD, "Recommendation of the Council on Digital Government Strategies," Public Gov. Territ. Dev. Dir., vol. July, p. 12, 2014.

[5] J. R. Gil-Garcia, S. S. Dawes, and T. A. Pardo, "Digital government and public management research: finding the crossroads," Public Manag. Rev., vol. 20, no. 5, pp. 633-646, 2018.

[6] J.R. Gil-García and T. A. Pardo, "E-government success factors: Mapping practical tools to theoretical foundations," Gov. Inf. Q., vol. 22, no. 2, pp. 187-216, 2005.

[7] UNITED NATIONS, "E-Government Survey 2018: Gearing E-Government to support transformation towards sustainable and resilient societies," New York, p. $270,2018$.

[8] World Economic Forum, "Government with the People: A New Formula for Creating Public Value," no. February, p. 18, 2017

[9] I. Mergel and K. C. Desouza, "Implementing open innovation in the public sector: The case of Challenge.gov," Public Adm. Rev., vol. 73, no. 6, pp. 882-890, 2013

[10] I. Mergel, Y. Gong, and J. Bertot, "Agile government: Systematic literature review and future research," Gov. Inf. Q., vol. 35, no. 2, pp. 291-298, 2018.

[11] OECD, "Strengthening Digital Government," no. March, p. 8, 2019.

[12] European Commission, "EU eGovernment Action Plan 2016-2020," Eur. Comm., no. 2016, 2016.

[13] V. Bekkers, L. Tummers, and W. Voorberg, "From public innovation to social innovation in the public sector: a literature review of relevant drivers and barriers," EGPA 2013 Conf., vol. 320090, no. 320090, pp. 1-38, 2013.

[14] B. Gupta, S. Dasgupta, and A. Gupta, "Adoption of ICT in a government organization in a developing country: An empirical study," f. Strateg. Inf. Syst., vol. 17, no. 2 , pp. $140-154,2008$.

[15] G. Stoker, "Governance?," pp. 41-57, 2006.

[16] T. B. Jørgensen and B. Bozeman, "Public Values," Adm. Soc., vol. 39, no. 3, pp. 354-381, 2007.

[17] J. Rose, J. S. Persson, L. T. Heeager, and Z. Irani, "Managing e-Government: Value positions and relationships," Inf. Syst. f., vol. 25, no. 5, pp. 531-571, 2015.

[18] P. Panagiotopoulos, B. Klievink, and A. Cordella, "Public value creation in digital government," Gov. Inf. Q., vol. 36, no. 4, 2019.

[19] A. Cordella and C. M. Bonina, "A public value perspective for ICT enabled public sector reforms: A theoretical reflection," Gov. Inf. Q., vol. 29, no. 4, pp. 512-520, 2012.

[20] F. Bannister and R. Connolly, "ICT, public values and transformative government: A framework and programme for research," Gov. Inf. Q., vol. 31, no. 1, pp. 119-128, 2014.

[21] J. D. Twizeyimana and A. Andersson, "The public value of E-Government - A literature review," Gov. Inf. Q., vol. 36, no. 2, pp. 167-178, 2019.

[22] A. Cordella and A. Paletti, "Government as a platform, orchestration, and public value creation: The Italian case," Gov. Inf. Q., vol. 36, no. 4, p. 101409, 2019.

[23] C. M. Bonina and A. Cordella, "Public sector reforms and the notion of "public value': Implications for e-government deployment," 15th Am. Conf. Inf. Syst. 2009, AMCIS 2009, vol. 1, pp. 469-476, 2009.

[24] C. Hood, "a Public Management for All Seasons?," Public Adm., vol. 69, no. 1, pp. 3-19, 1991.

[25] A. A. Golubeva and E. V. Gilenko, Electronic Governance and Open Society: Challenges in Eurasia, vol. 947. Springer International Publishing, 2019.

[26] A. Cordella and C. Dodd, "It takes two to tango: Bringing together users and artificial intelligence to create public value," ACM Int. Conf. Proceeding Ser., pp. 389-397, 2019.

[27] J. Rose, L. S. Flak, and Ø. Sæbø, "Stakeholder theory for the E-government context: Framing a value-oriented normative core," Gov. Inf. Q., vol. 35, no. 3, pp. 362-374, 2018.

[28] L. F. Luna-Reyes, R. Sandoval-Almazan, G. Puron-Cid, S. Picazo-Vela, D. E. Luna, and J. R. Gil-Garcia, "Preface," Lect. Notes Comput. Sci. (including Subser. Lect. Notes Artif. Intell. Lect. Notes Bioinformatics), vol. 10428 LNCS, pp. V-VI, 2017.

[29] L. Lessa and A. Tsegaye, "Evaluation of the public value of e-government services in Ethiopia: Case of court case management system," ACM Int. Conf. Proceeding Ser., vol. Part F1481, pp. 21-26, 2019.

[30] I. Lindgren and A. F. van Veenstra, "Digital government transformation," pp. 1-6, 2018.

[31] D. Valle-Cruz, "Public value of e-government services through emerging technologies," Int. f. Public Sect. Manag., vol. 32, no. 5, pp. 473-488, 2019.

[32] L. F. Luna-Reyes, S. Picazo-Vela, D. E. Luna, and J. R. Gil-Garcia, "Creating public value through digital government: Lessons on inter-organizational collaboration and information technologies," Proc. Annu. Hawaii Int. Conf. Syst. Sci., vol. 2016March, pp. 2840-2849, 2016.

[33] S. Picazo-Vela, I. Gutiérrez-Martínez, F. Duhamel, D. E. Luna, and L. F. Luna-Reyes, "Value of inter-organizational collaboration in digital government projects," Public Manag. Rev., vol. 20, no. 5, pp. 691-708, 2018. 
[34] D. Tranfield, D. Denyer, and P. Smart, "Towards a Methodology for Developing Evidence-Informed Management Knowledge by Means of Systematic Review," Br. f. Manag., vol. 14, no. 3, pp. 207-222, 2003.

[35] D. Moher et al., "Preferred reporting items for systematic reviews and metaanalyses: The PRISMA statement," PLoS Med., vol. 6, no. 7, 2009.

[36] D. Toll, I. Lindgren, U. Melin, and C. Madsen, "Values, benefits, considerations and risks of ai in government: A study of ai policy documents in sweden," efournal eDemocracy Open Gov., vol. 12, no. 1, pp. 40-60, 2020

[37] J. P. Roy, "Service, openness and engagement as digitally-based enablers of public value? A critical examination of digital government in Canada," Int. f. Public Adm. Digit. Age, vol. 6, no. 3, pp. 23-40, 2019.

[38] K. Fröhlich and A. Peters, "A model for designing, implementing and evaluating citizen-centric e-Government in Namibia," Lect. Notes Inst. Comput. Sci. Soc. Telecommun. Eng. LNICST, vol. 250, pp. 3-15, 2018.

[39] I. Ferreira and L. A. Amaral, "Public e-procurement: Advantages, limitations and technological 'pitfalls,"' ACM Int. Conf. Proceeding Ser., vol. 01-03-Marc, pp. 9-12, 2016.

[40] D. E. Luna, A. Duarte-Valle, S. Picazo-Vela, and L. F. Luna-Reyes, "Digital governance and public value creation at the state level," Inf. Polity, vol. 20, no. 2-3, pp. 167-182, 2015.

[41] M. Yildiz and A. Saylam, "E-government discourses: An inductive analysis," Gov. Inf. Q., vol. 30, no. 2, pp. 141-153, 2013

[42] A. Cordella and L. Willcocks, "Government policy, public value and IT outsourcing: The strategic case of ASPIRE," 7. Strateg. Inf. Syst., vol. 21, no. 4, pp. 295-307, 2012.

[43] K. Karunasena and H. Deng, "Critical factors for evaluating the public value of e-government in Sri Lanka," Gov. Inf. Q., vol. 29, no. 1, pp. 76-84, 2012.

[44] E. M. Luciano and G. C. Wiedenhöft, "The role of organizational citizenship behavior and strategic alignment in increasing the generation of public value through digital transformation," ACM Int. Conf. Proceeding Ser., pp. 494-501, 2020

[45] A. Ranerup and H. Z. Henriksen, "Value positions viewed through the lens of automated decision-making: The case of social services," Gov. Inf. Q., vol. 36, no. 4, p. 101377, 2019.

[46] D. Trutnev and L. Vidiasova, Electronic Government - 18th IFIP WG 8.5 International Conference, EGOV 2019, San Benedetto Del Tronto, Italy, September 2-4, 2019, Proceedings, vol. 11685. Springer International Publishing, 2019.
[47] P. Müller and S. Trui, "Behind the Scenes of Coproduction of Smart Mobility: Evidence from a Public Values' Perspective," vol. 11685, pp. 301-310, 2019.

[48] G. Puron-Cid, "From technology to social development. Applying a public value perspective to digital government in local governments in Mexico," ACM Int. Conf. Proceeding Ser., vol. Part F1282, pp. 336-345, 2017.

[49] G. V. Pereira, L. F. Luna-Reyes, and J. R. Gil-Garcia, "Governance innovations, digital transformation and the generation of public value in Smart City initiatives," ACM Int. Conf. Proceeding Ser., pp. 602-608, 2020.

[50] E. Dobrolyubova, E. Klochkova, and O. Alexandrov, "Digitalization and Effective Government: What Is the Cause and What Is the Effect?" Commun. Comput. Inf. Sci., vol. 1038 CCIS, pp. 55-67, 2019.

[51] M. Chantillon, J. Crompvoets, and V. Peristeras, "Prioritizing public values in egovernment policies: A document analysis," Inf. Polity, vol. 25, no. 3, pp. 275-300, 2020.

[52] S. Ølnes, J. Ubacht, and M. Janssen, "Blockchain in government: Benefits and implications of distributed ledger technology for information sharing," Gov. Inf. Q., vol. 34, no. 3, pp. 355-364, 2017.

[53] Y. Liang, G. Qi, X. Zhang, and G. Li, "The effects of e-Government cloud assimilation on public value creation: An empirical study of China," Gov. Inf. Q., vol. 36, no. 4 , p. $101397,2019$.

[54] M. Cook and T. M. Harrison, "Using public value thinking for government IT planning and decision making: A case study," Inf. Polity, vol. 20, no. 2-3, pp. 183-197, 2015.

[55] S. R. Chohan, G. Hu, W. Si, and A. T. Pasha, "Synthesizing e-government maturity model: a public value paradigm towards digital Pakistan," Transform. Gov. People, Process Policy, vol. 14, no. 3, pp. 495-522, 2020.

[56] A. Savoldelli, C. Codagnone, and G. Misuraca, "Understanding the e-government paradox: Learning from literature and practice on barriers to adoption," Gov. Inf. O., vol. 31, no. SUPPL.1, pp. S63-S71, 2014.

[57] W. Castelnovo, "A stakeholder based approach to public value," Proc. Eur. Conf. e-Government, ECEG, no. January, pp. 94-101, 2013.

[58] A. F. Van Veenstra and M. Janssen, "Investigating outcomes of t-government using a public value management approach," Lect. Notes Comput. Sci. (including Subser. Lect. Notes Artif. Intell. Lect. Notes Bioinformatics), vol. 7443 LNCS, pp. 187-197, 2012.

\section{APPENDIX A - E-GOVERNMENT EXPECTED BENEFITS}

Positive effects deriving from the development of e-Government projects

$\begin{array}{ll}\text { Improved } & \text { Benefit } \\ \text { Improved administrative efficiency }\end{array}$

Administration

\section{Improved administrative efficiency}

Accountability within public [20], [45], [51]

organization

Cost reduction and savings

[36], [39], [45], [52], [53]

Competitiveness

Efficiency

[18], [23], [36], [43], [50], [53]

Effectiveness

Process automation

[26], [36], [45]

Errors reduction

[36], [52]

Process optimization sustainability

[21], [36]

Governance

Better management of public

resources and funds

Data immutability

Predictive capabilities
Explanation

e-Government projects enhance responsibility within the organization.

e-Government projects could impact on cost, both considering human resources and process management.

e-Government projects could improve the competitiveness of public organizations. Developing e-Government projects allows public organizations to reduce resources usage while ensuring the same services.

Due to the adoption of digital technologies, new resources and services are provided.

Digital technologies adoption impacts on process automation.

e-Government projects could reduce human mistakes. e-Government projects could make operations and processes more systematic and sustainable.

Digital technologies could enhance processes control and resource management.

Digital technologies could support public organizations in the proper use of public resources. e-Government projects could improve data integrity and the quality of information.

Digital technologies could impact on data preservation.

Digital technologies could enable to retrace data history, thus enhancing the capability to forecast actions or behaviours. 
Reduced energy consumption

Increased resilience

Economy and parsimony

[20], [23]

Open Government capabilities

Transparency and openness

[18], [20], [21], [39], [48], [52]

Information quality

[21], [39], [43], [52], [53]

Stakeholder interaction

[18], [21], [36], [51]

Information management

[39], [52]

Improved ethical behaviour and professionalism

Law compliance

[20], [51]

Political Loyalty

Judicial values

[20], [51]

Control of corruption

$[50]-[52]$

Accountability towards society

[18], [20], [50], [51]

Rectitude and impartiality

[20], [51]

Responsibility to stakeholder

[20], [51]

Enhance protection for different stakeholder

[20], [51]

Honesty and fairness

[18], [20], [23]

Improved Public

Services
[18], [36]

[26]

[18], [20], [48], [51]

[20], [51]

[18], [21], [26], [29], [36], [43], [45], [48], [51], [53]

Better management of public resources and funds

Responsiveness

[20], [43], [51]

Respect for the individual
The features of specific technologies (i.e. blockchain) could reduce energy usage.

Digital technologies could enhance public organization capabilities to prevent malicious actions. Digital technologies could support public organizations in the usage of money.

e-Government projects could increase the access to public data assets and to public organization's activities.

The implementation of e-Government projects could enhance quality of information, considering relevance, accuracy, update and access.

The development of e-Government projects is expected to facilitate the interaction among public organizations and different stakeholders. Digital technologies could support public organizations in data and information management.

Digital technologies could support public servants to act in compliance with the law.

e-Government projects are expected to positively impact on political loyalty.

The adoption of digital technologies could support civil servants to act following judicial values.

Public organizations could leverage on digital technologies to control corruption.

e-Government projects impact on the communication to external stakeholder regarding the resources usage and ensuring that the activities carried out follow institutional mission.

Digital technologies could support public servants to act with rectitude and impartiality.

e-Government projects enhance the responsibility to citizens, enterprises, organizations.

The adoption of digital technologies is expected to enhance public organization capabilities to protect stakeholder.

e-Government projects are expected to positively enhance honest and fair behaviours.

The usage of digital technologies could increase service accessibility.

The usage of digital technologies could increase the interaction with users.

Adopting digital technologies allows public organizations to deliver the same services reducing resources usage.

Due to the enhancement of e-Government projects, public organization could provide new services. The progressive adoption of digital technologies is expected to increase innovation orientation. e-Government projects are expected to increase productivity in service delivery.

Through the usage of digital technologies, governments could better satisfy user needs. e-Government projects are expected to enhance service in terms of personalization, quality, ease of usage, delivery.

Digital technologies could support public organizations in the proper use of public resources. Thanks to digital technologies, public organizations could better satisfy citizens' needs.

e-Government projects could support public organizations to better understand the needs of individuals and thus respecting them. 


\begin{tabular}{|c|c|c|c|}
\hline & \multicolumn{3}{|c|}{ Improved trust and confidence in government } \\
\hline \multirow[t]{17}{*}{$\begin{array}{l}\text { Improved } \\
\text { Social Value }\end{array}$} & Enhance networks development & {$[51]$} & $\begin{array}{l}\text { Digital technologies are expected to improve public } \\
\text { organization in creating networks. }\end{array}$ \\
\hline & $\begin{array}{l}\text { Dialogue within other public } \\
\text { organizations }\end{array}$ & {$[51]$} & $\begin{array}{l}\text { e-Government projects implementation could } \\
\text { facilitate the interaction between different } \\
\text { governments. }\end{array}$ \\
\hline & User orientation & {$[23]$} & $\begin{array}{l}\text { Through the adoption of digital technologies public } \\
\text { organization could act focusing more on citizens' and } \\
\text { stakeholder. }\end{array}$ \\
\hline & Balance competing interests & {$[51]$} & $\begin{array}{l}\text { Due to digital technologies implementation, public } \\
\text { organizations could better manage the competing } \\
\text { expectations of the various stakeholder. }\end{array}$ \\
\hline & Privacy & {$[18],[20],[52]$} & $\begin{array}{l}\text { e-Government projects could positively influence } \\
\text { users privacy and anonymity. }\end{array}$ \\
\hline & Stakeholder interaction & {$[18],[20],[21],[26],[36],[51]$} & $\begin{array}{l}\text { The adoption of digital technologies is expected to } \\
\text { facilitate the interaction among public organizations } \\
\text { and different stakeholders. }\end{array}$ \\
\hline & Equality and equity in service access & {$[18],[20],[23],[36],[51]$} & $\begin{array}{l}\text { e-Government projects could increase the access to } \\
\text { public services, thus making them more inclusive. }\end{array}$ \\
\hline & Transparency and openness & {$[18],[20],[21],[48],[52]$} & $\begin{array}{l}\text { Digital technologies could increase the access to } \\
\text { public data assets and to public organization's } \\
\text { activities. }\end{array}$ \\
\hline & Security & {$[20],[52]$} & $\begin{array}{l}\text { Digital technologies within public organizations could } \\
\text { reduce data manipulation, thus citizens' security. }\end{array}$ \\
\hline & Trust and confidence & {$[39],[52]$} & $\begin{array}{l}\text { e-Government projects impact on the confidence } \\
\text { perceived by stakeholder in public organizations. }\end{array}$ \\
\hline & Accountability towards society & {$[18],[20],[45],[50],[51]$} & $\begin{array}{l}\text { e-Government projects impact on the communication } \\
\text { to external stakeholder regarding the resources usage } \\
\text { and ensuring that the activities carried out follow } \\
\text { institutional mission. }\end{array}$ \\
\hline & \multicolumn{3}{|c|}{ Improved social value and well being } \\
\hline & Facilitating the democratic will & {$[20],[51]$} & $\begin{array}{l}\text { e-Government projects could facilitate democratic } \\
\text { activities and participation. }\end{array}$ \\
\hline & Respect for individual & {$[20]$} & $\begin{array}{l}\text { Digital technologies could support public } \\
\text { organizations to better understand the needs of } \\
\text { individuals and thus respecting them. }\end{array}$ \\
\hline & Environmental sustainability & {$[43]$} & $\begin{array}{l}\text { The implementation of e-Government projects could } \\
\text { positively influence environmental impacts. }\end{array}$ \\
\hline & Inclusiveness & {$[20]$} & $\begin{array}{l}\text { e-Government projects are expected to increase } \\
\text { public organizations capabilities to be more inclusive. }\end{array}$ \\
\hline & Control of corruption & {$[39],[50]-[52]$} & $\begin{array}{l}\text { Public organizations could leverage on digital } \\
\text { technologies to control corruption. }\end{array}$ \\
\hline
\end{tabular}




\section{APPENDIX B - E-GOVERNMENT ENABLING CONDITIONS}

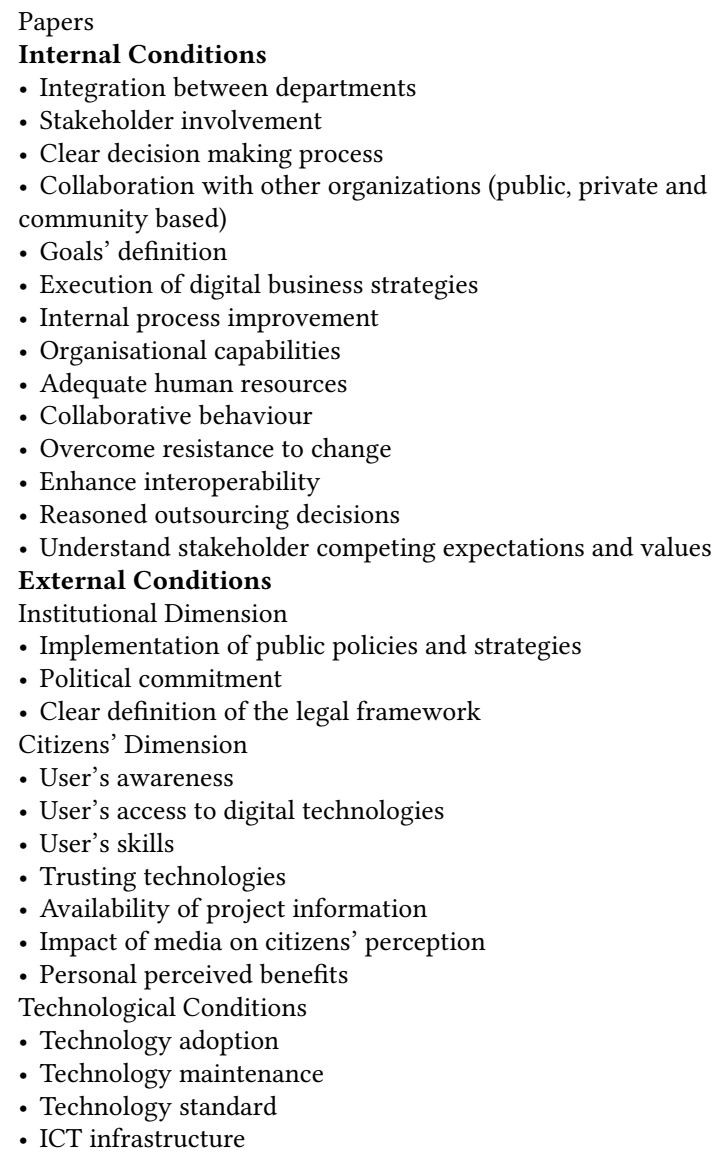

[55]

[37], [47], [55], [56]

[30], [44], [54]

[30], [32], [33], [38]

[32]

[44]

[32], [33]

[18], [37], [44], [56]

$[49]$

$[44]$

$[56]$

$[56]$

$[42]$

[18], [27], [30], [38], [47], [56], [57]

[31], [37], [56]

[56]

[30], [32]

[25], [38], [46]

[25], [38], [55]

[25], [38]

[25]

[46]

[41]

[25], [46]

[49]

$[56]$

$[32$

[38], [56]

\section{APPENDIX C - E-GOVERNMENT PROJECTS IMPACTS}

\begin{tabular}{ll}
\hline & Papers \\
Internal Perspective & {$[20]-[23],[26],[39],[43],[50],[52],[53]$} \\
External Perspective & {$[18],[20],[48],[50],[21],[23],[26],[29],[39],[40],[43],[45]$} \\
Broad Perspective & {$[5],[36],[51]$} \\
\hline
\end{tabular}

